\title{
Translocation and Metabolism of Procymidone in Cucumber and Bean Plants
}

\author{
Nobuyoshi Mikami, Jun Yoshimura, Hirohiko Yamada \\ and Junshi Miyamoto \\ Laboratory of Biochemistry and Toxicology, Takarazuka Research Center, \\ Sumitomo Chemical Co., Ltd., Takatsukasa, Takarazuka 665, Japan
}

(Received September 12, 1983)

\begin{abstract}
Translocation and metabolism of a systemic fungicide procymidone [Sumilex ${ }^{\circledR}, N-(3,5$ dichlorophenyl)-1,2-dimethylcyclopropane-1,2-dicarboximide] radiolabeled at the carbonyl carbon were examined in cucumber and bean plants under laboratory conditions. The fungicide disappeared from the plants with a half-life of 20 days, after foliar application at a rate of $250 \mu \mathrm{g}$ per leaf. Procymidone was metabolized in plants via hydroxylation at the methyl group or the 4-position of phenyl group, or hydrolysis at the cyclic imide linkage. Very little of radioactivity translocated to other parts of the plants including edible portions. When the fungicide was applied to the surface of a cucumber fruit, approximately $24 \%$ of the applied radioactivity penetrated into the fruit in a day. However, there was no significant increase of radioactivity in the fruit thereafter. When bean plant seedlings were cultivated for 42 days in Kodaira light clay and Takarazuka loamy sand soils treated with $10 \mathrm{ppm}$ of ${ }^{14} \mathrm{C}$-procymidone, shoots, and pods and seeds contained $12.3-15.3 \mathrm{ppm}$ and $0.42-$ $0.66 \mathrm{ppm}$ of ${ }^{14} \mathrm{C}$, respectively. Preincubation of procymidone treated soils for up to 5 months significantly lowered ${ }^{14} \mathrm{C}$ residues taken up in plants, especially in shoots and pods and seeds.
\end{abstract}

\section{INTRODUCTION}

Procymidone [Sumilex ${ }^{\circledR}, N$ - (3,5-dichlorophenyl)-1,2-dimethylcyclopropane-1,2 - dicarboximide] is a systemic fungicide for the control of plant diseases such as gray mould of grape and vegetable crops, and Sclerotinia rot of kidney beans and vegetable crops. ${ }^{1-3)}$ From the point of environmental safety, study on metabolism of procymidone in rats had already been performed and it was shown that the fungicide was biodegradable and not persistent in animal bodies even after repeated oral administration. ${ }^{4}$ )

This report is concerned with the translocation and metabolism of procymidone in cucumber and kidney bean plants after leaf, fruit or root treatment of ${ }^{14} \mathrm{C}$ preparation labeled at the carbonyl group.

\section{MATERIALS AND METHODS}

\section{Chemicals}

Procymidone labeled with ${ }^{14} \mathrm{C}$ at the carbonyl group was synthesized by Yoshitake et al. ${ }^{5)}$ in Takarazuka Research Center of Sumitomo Chemical Co., Ltd. The specific activity was $4.67 \mathrm{mCi} / \mathrm{mmol}$ with more than $99.9 \%$ of radiochemical purity as determined by thin layer chromatography (TLC), radioautography and liquid scintillation counting. Unlabeled procymidone and the following compounds were prepared for the reference ${ }^{6)}: N$-(4-hydroxy-3,5dichlorophenyl)-1,2-dimethylcyclopropane-1,2dicarboximide[referred to $\mathrm{P}-4-\mathrm{OH}], 2-(3,5-\mathrm{di}-$ chlorophenylcarbamoyl) -1,2-dimethylcyclopropane-1-carboxylic acid [P-NH-COOH], N-(3, 5-dichlorophenyl)-1-hydroxymethyl-2-methylcyclopropane-1,2-dicarboximide $\left[\mathrm{P}-\mathrm{CH}_{2} \mathrm{OH}\right]$, $N$-(3-chlorophenyl)-1,2-dimethylcyclopropane1,2-dicarboximide [P-3-Cl] and 1,2-dimethyl- 
Table 1 Thin-layer chromatographic properties of procymidone and its metabolites.

\begin{tabular}{lccc}
\hline \multirow{2}{*}{ Compound } & \multicolumn{3}{c}{$\begin{array}{c}\text { Rf values with indicated } \\
\text { solvent systems }\end{array}$} \\
\cline { 2 - 4 } & A & B & C \\
\hline Procymidone & 0.58 & 0.41 & 0.55 \\
P-3-Cl & 0.54 & 0.36 & 0.34 \\
P-4-OH & 0.42 & 0.22 & 0.26 \\
P-NH-COOH & 0.08 & 0.14 & 0.17 \\
P-CH ${ }_{2} \mathrm{OH}$ & 0.17 & 0.18 & 0.14 \\
CP- $(\mathrm{COOH})_{2}$ & 0.01 & 0.04 & 0.12 \\
\hline
\end{tabular}

a) A: chloroform/ethyl acetate (4/1), B: nhexane/acetone (5/2), C: toluene/acetic acid (7/1).

cyclopropane-1,2-dicarboxylic acid [CP-(CO$\left.\mathrm{OH})_{2}\right]$.

\section{Radioassay}

Liquid scintillation counting (LSC), combustion analysis and radioautography were carried out according to the methods reported previously. ${ }^{\text {) }}$

\section{Thin Layer Chromatography}

Precoated silica gel 60F-254 chromatoplates $(20 \times 20 \mathrm{~cm}, \quad 0.25 \mathrm{~mm}$ layer thickness, E. Merck) were used for an analytical purpose. The $R f$ values for procymidone and its metabolites are listed in Table 1 . The radioactive compounds were detected by autoradiography and unlabeled compounds were detected by UV light or by exposure to iodine vapor.

\section{Foliar Treatment of Cucumber and Bean Plants}

A six-week old cucumber plant (Cucumis satious L. cv Kurumeochiai $\mathrm{H}$-type), bearing two to three fruits per plant, in Wagner pots $(26.5 \mathrm{~cm}$ i.d. $\times 30 \mathrm{~cm}$ height) with soil, and five-week old kidney bean plants (Phaseolus vulgaris L.) in the stage of flowering were selected in the experiment. These plants were held in a greenhouse at $25 \pm 2{ }^{\circ} \mathrm{C}$ with a relative humidity of 40 to $80 \%$ before or after treatment. The weight of cucumber fruits was $c a$. $5 \mathrm{~g}$ at the time of treatment and $c a .20 \mathrm{~g}$ at harvest. ${ }^{14} \mathrm{C}$-Procymidone was diluted with four parts of a $1: 9$ mixture (w/v) of emulsifying agent (Hymal PS-10AS, Matsumoto Yushi Seiyaku) and isophorone, and then mixed with water to form an aqueous suspension with a concentration of $500 \mathrm{ppm}$ active ingredient. This suspension $(0.5 \mathrm{ml})$ was evenly applied to the upper surface of the 6th cucumber leaf in the vicinity of a fruit bearing area, or of the 4th leaf of bean plants at a rate of $250 \mu \mathrm{g}$ per leaf by a micropipette. This treatment was calculated from a practical application rate of $1.5 \mathrm{~kg} / \mathrm{ha}$ in the field.

At specified intervals, two of the cucumber and bean plants were harvested, and divided into a treated leaf, other untreated leaves and stems (designated as shoots) and into edible and root portions. The treated leaf was rinsed three times with $50 \mathrm{ml}$ of acetone (surface wash) and then homogenized in methanol/ chloroform $(2 / 1)$ with a Waring blender to extract internal radiocarbon (extract). The homogenate was filtered and the residue was reextracted twice with the same solvent system. Both shoots and edible portions were extracted in the same way as described above. The root portions were thoroughly washed with tap water, frozen in liquid nitrogen and ground to a fine powder with a mortar and pestle. The homogenate was extracted twice with $50 \mathrm{ml}$ of methanol for ${ }^{14} \mathrm{C}$ analysis.

\section{Cucumber Fruit Treatment}

Potted 8-week old cucumber plants were used in the experiment. ${ }^{14} \mathrm{C}$-Procymidone in ether $(1.5 \mathrm{ml})$ was applied to the surface of the cucumber fruits $(c a .30-40 \mathrm{~g})$ by a brush at a rate of $300 \mu \mathrm{g}$ per fruit, and held in a greenhouse at $25 \pm 2{ }^{\circ} \mathrm{C}$ for up to 12 days. At specified intervals, two treated fruits were removed and washed three times with $50 \mathrm{ml}$ of acetone (surface wash). Then, the fruits were cut into small pieces and homogenized in a mixer for $10 \mathrm{~min}$ with $5 \mathrm{ml}$ of methanol/chloroform (2/1) per gram plant material. The mixture was filtered and the residue on the filter paper was rinsed with more solvent (extract).

\section{Uptake of Soil Residues by Bean Plants}

Characterization of soil used for this study is as follows. Kodaira light clay soil with sand, silt, clay and organic matter contents of $31,40,29 \%$ 
and $15.3 \%$, respectively, $\mathrm{pH}\left(\mathrm{H}_{2} \mathrm{O}\right) 5.5$; Takarazuka loamy sand soil with sand, silt, clay and organic matter contents of $95,3,2 \%$ and $2.7 \%$, respectively, $\mathrm{pH}\left(\mathrm{H}_{2} \mathrm{O}\right)$ 7.0. Detailed characteristics of the soils were reported previously. ${ }^{8)}$ ${ }^{14} \mathrm{C}$-Procymidone was applied at a rate of 10 ppm on dry weight basis, and the soils were mixed well, and then each $300 \mathrm{~g}$ soil sample was placed into a plastic pot $(11 \mathrm{~cm}$ i.d. $\times 7 \mathrm{~cm}$ height). The treated soil sample was moistened to $40 \%$ of the maximum water-holding capacity and incubated for 2 weeks or 5 months at 25 $\pm 2^{\circ} \mathrm{C}$ in the dark. Then, 14-day old seedlings of kidney bean plants were transplanted into the pots and held in a greenhouse at $25 \pm 2{ }^{\circ} \mathrm{C}$. About $30-50 \mathrm{ml}$ of water was applied to each pot every day. After 42 days, the plants were carefully pulled out of the soils and the roots were thoroughly washed with $200 \mathrm{ml}$ of water. The harvested plants were sectioned into roots, shoots and edible portions, and each part of the plant was analyzed as mentioned above. The soil was extracted three times with $900 \mathrm{ml}$ of ethyl acetate $/ 1 \mathrm{~N} \mathrm{HCl}(2 / 1)$ by shaking for $10 \mathrm{~min}$ followed by centrifugation at $500 \mathrm{rpm}$ for $15 \mathrm{~min}$. The soil residue was reextracted twice in the same solvent system. The combined ethyl acetate extract and aqueous layer were radiocounted, and the organic layer was concentrated and examined by TLC. The unextracted soil residue was combusted to ${ }^{14} \mathrm{CO}_{2}$ prior to LSC.

\section{RESULTS AND DISCUSSION}

\section{Foliar Treatment}

After the foliar application of ${ }^{14} C$-procymidone to cucumber and bean plants at a rate of $250 \mu \mathrm{g}$ per leaf, recovery of the total radiocarbon gradually decreased. From the cucumber plants $63.6 \%$ of the applied ${ }^{14} \mathrm{C}$ was recovered after 23 days, and $38.7 \%$ from bean plants after 30 days (Table 2). Most of the recovered ${ }^{14} \mathrm{C}$ was found in the treated leaves, with less than $3 \%$ of the applied ${ }^{14} \mathrm{C}$ in other parts of the plants.

At harvest, $25 \mathrm{ppb}$ and $17 \mathrm{ppb}$ procymidone equivalent to the radiocarbon were present in the edible portions of cucumber and bean plants, respectively (Table 3). Shoots contained $38 \mathrm{ppb}$ to $19 \mathrm{ppb}$ procymidone equivalent to the radiocarbon, whereas no ${ }^{14} \mathrm{C}$ was detected in roots. The evidence indicates that very little ${ }^{14} \mathrm{C}$ translocated from the treated leaves to other parts of the plants including the edible portions. However, the findings were not consistent with those of the previous studies on cucumber young seedlings, ${ }^{2}$ ) which showed that approximately $15 \%$ of the applied

Table 2 Metabolism of procymidone in cucumber and kidney bean plants after foliar or fruit treatment with ${ }^{14} \mathrm{C}$ preparation.

\begin{tabular}{|c|c|c|c|c|c|c|}
\hline \multirow[b]{3}{*}{ Days after application } & \multicolumn{6}{|c|}{$\%$ of the applied ${ }^{14} \mathrm{C}$} \\
\hline & \multicolumn{2}{|c|}{ Cucumber $^{\text {a) }}$} & \multicolumn{2}{|c|}{ Bean $\left.^{a}\right)$} & \multicolumn{2}{|c|}{ Cucumber fruits $\left.{ }^{b}\right)$} \\
\hline & 8 & 23 & 12 & 30 & 5 & 12 \\
\hline \multicolumn{7}{|l|}{ Treated leaves or fruits } \\
\hline Surface wash & 73.2 & 45.5 & 52.4 & 29.9 & 44.7 & 38.9 \\
\hline Procymidone & 73.2 & 45.5 & 51.2 & 28.4 & 44.7 & 38.9 \\
\hline $\mathrm{P}-\mathrm{NH}-\mathrm{COOH}$ & $<0.1$ & $<0.1$ & 0.8 & 1.3 & $<0.1$ & $<0.1$ \\
\hline Others & $<0.1$ & $<0.1$ & 0.4 & 0.2 & $<0.1$ & $<0.1$ \\
\hline Extract & 9.5 & 18.0 & 5.2 & 8.3 & 22.2 & 20.4 \\
\hline Procymidone & 9.1 & 17.3 & 4.9 & 7.7 & 21.4 & 19.0 \\
\hline P-NH-COOH & 0.2 & 0.1 & 0.1 & 0.1 & 0.4 & 0.2 \\
\hline $\mathrm{P}-4-\mathrm{OH}$ & $<0.1$ & 0.1 & $<0.1$ & 0.1 & 0.1 & 0.2 \\
\hline $\mathrm{P}-\mathrm{CH}_{2} \mathrm{OH}$ & $<0.1$ & 0.1 & $<0.1$ & 0.1 & $<0.1$ & 0.1 \\
\hline Others & 0.2 & 0.4 & 0.2 & 0.3 & 0.3 & 0.9 \\
\hline Pulps & $<0.1$ & 0.1 & 0.1 & 0.5 & 3.5 & 4.9 \\
\hline Total & 82.7 & 63.6 & 57.7 & 38.7 & 70.4 & 64.2 \\
\hline
\end{tabular}

a) foliar treatment, b) fruit treatment. 
Table 3 Residue levels of radiocarbon in cucumber and bean plants after foliar application of ${ }^{14} \mathrm{C}$-procymidone at a rate of $250 \mu \mathrm{g}$ per leaf.

\begin{tabular}{|c|c|c|}
\hline & \multicolumn{2}{|c|}{$\begin{array}{l}{ }^{14} \mathrm{C}, \mathrm{ppm} \text { procymi- } \\
\text { done equivalent }\end{array}$} \\
\hline & Cucumber $\left.{ }^{a}\right)$ & Bean $^{b}$ ) \\
\hline Treated leaves ( 0 day) & 40 & 120 \\
\hline \multicolumn{3}{|l|}{ At harvest } \\
\hline Treated leaves & 18 & 38 \\
\hline Shoots & 0.038 & 0.019 \\
\hline Edible portions & 0.025 & 0.017 \\
\hline Roots & $<0.001$ & $<0.001$ \\
\hline
\end{tabular}

a) after 23 days, b) after 30 days.

${ }^{14} \mathrm{C}$ translocated from the treated leaves to the untreated upward and downward portions. This difference might be due at least in part to the difference in the developmental stage of plants to which procymidone had been applied.

As shown in Fig. 1, the fungicide disappeared from the treated leaves of cucumber and bean plants with a half-life of approximately 20 days, and at harvest declined to $62.8 \%$ and $36.1 \%$ of the applied dose. Together with a large amount of unchanged procymidone, four minor metabolites were detected by silica gel TLC in either solvent system A or B, and three metabolites were identified by TLC cochromatography with the authentic standards. All of the products were procymidone derivatives cleaved at the cyclic imide linkage (P-NH$\mathrm{COOH})$, and hydroxylated at the methyl group $\left(\mathrm{P}-\mathrm{CH}_{2} \mathrm{OH}\right)$ and at the 4-position of phenyl group $(\mathrm{P}-4-\mathrm{OH})$, which amounted in total to less than $2 \%$ of the applied ${ }^{14} \mathrm{C}$ in cucumber and bean plants. The shoots, roots and edible portions were not analyzed for ${ }^{14} \mathrm{C}$ because of lower radiocarbon levels.

\section{Fruit Treatment}

When cucumber fruits were treated with ${ }^{14} \mathrm{C}$-procymidone at a rate of $7.5-10 \mathrm{ppm}$, approximately $24 \%$ of the applied ${ }^{14} \mathrm{C}$ penetrated into the fruits one day after treatment and located mainly in the peeled fraction. Nevertheless, there was no significant increase in the amount of radiocarbon thereafter. After 12 days, approximately $64 \%$ of the applied

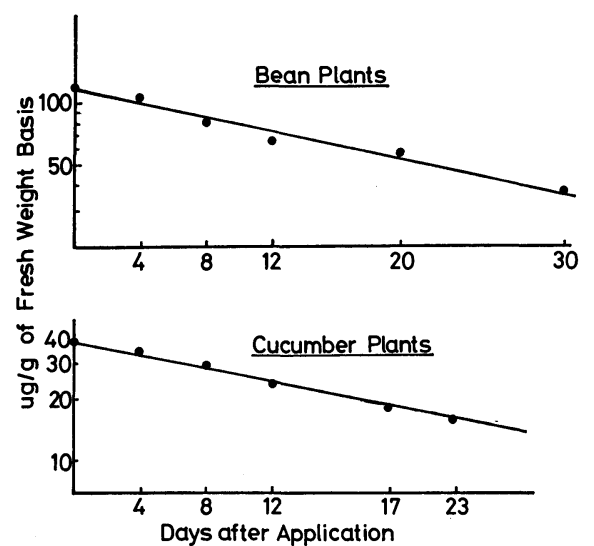

Fig. 1 Residue levels of procymidone in the treated leaves of bean and cucumber plants after foliar application.

${ }^{14} \mathrm{C}$ was recovered from the cucumber fruits under the greenhouse conditions (Table 2). However, procymidone disappeared much more rapidly from the cucumber fruits with halflives of 3-7 days under practical field conditions. ${ }^{9)}$

On the treated fruits only unchanged procymidone was detected and no degradation product was observed with a sufficient quantity to permit the detection on TLC, whereas trace amounts of P-NH-COOH, P-4-OH and $\mathrm{P}-\mathrm{CH}_{2-}$ $\mathrm{OH}$ occurred in the fruits.

\section{Uptake of Soil Residues by Bean Plants}

Kidney bean seedlings were grown for up to 42 days in the soil treated with $10 \mathrm{ppm}$ of ${ }^{14} \mathrm{C}$ procymidone, and the radiocarbon in shoots, roots and edible portions was determined (Fig. 2). Although the shoots contained 12.3 ppm procymidone equivalent to ${ }^{14} \mathrm{C}$ with Kodaira soil and $15.3 \mathrm{ppm}$ with Takarazuka soil, the concentration in the edible portions was $0.42 \mathrm{ppm}$ and $0.66 \mathrm{ppm}$ with Kodaira and Takarazuka soils, respectively. Approximately $5-6 \mathrm{ppm}$ of ${ }^{14} \mathrm{C}$ residue was found in roots with both soils. When bean seedlings were transplanted in the soil preincubated with $10 \mathrm{ppm}$ of ${ }^{14} \mathrm{C}$-procymidone for 5 months, the ${ }^{14} \mathrm{C}$ residues in plants were lower than in those without preincubation. After 42 days, shoots, pods and seeds contained $5.2-6.1 \mathrm{ppm}$ and $0.33-0.38 \mathrm{ppm}$ procymidone equivalent to ${ }^{14} \mathrm{C}$, 


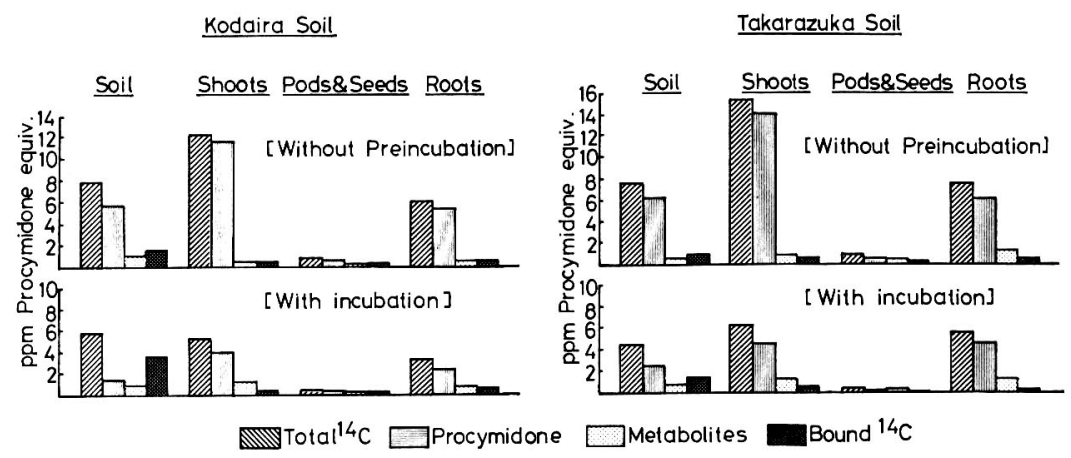

Fig. 2 Uptake and distribution of ${ }^{14} \mathrm{C}$ in bean plants 42 days after transplantation to Kodaira and Takarazuka soils treated with ${ }^{14} \mathrm{C}$-procymidone at the rate of $10 \mathrm{ppm}$.

respectively.

Procymidone amounted to approximately $80-90 \%$ of the radiocarbon in shoots and roots, and $30-65 \%$ in pods and seeds. The metabolites found in the leaves treated with ${ }^{14} \mathrm{C}$ procymidone such as $\mathrm{P}-\mathrm{NH}-\mathrm{COOH}, \mathrm{P}-4-\mathrm{OH}$ and $\mathrm{P}-\mathrm{CH}_{2} \mathrm{OH}$ were also detected in shoots and roots, but none in the edible portions. Most of the metabolites in pods and seeds were polar and located at the origin of silica gel TLC in solvent system A. Although further characterization is yet to be carried out, they may be conjugated metabolites. Thus, procymidone residue in soil is readily taken up by bean plants, and translocated to shoots except for the edible portions. The lower concentration of procymidone in pods and seeds may be caused by lower transpiration capacity of the edible portions. Such a distribution pattern has been observed in tomato when benomyl was used as a systemic fungicide. ${ }^{10)}$

A slightly large amount of radiocarbon was found in bean plants grown in Takarazuka soil with a lower organic matter content than in Kodaira soil with a higher organic matter content. This appears to relate to more extensive adsorption of procymidone to Kodaira soil ${ }^{11}$ which results in reduction of an amount of a fungicide available for plant uptake as in the case of other pesticides. ${ }^{12-14)}$

In the treated Kodaira and Takarazuka soils, at least seven degradation products were detected on silica gel TLC in solvent system $\mathrm{A}$ or $\mathrm{B}$, and $\mathrm{P}-\mathrm{NH}-\mathrm{COOH}, \mathrm{P}-4-\mathrm{OH}, \mathrm{P}-3-\mathrm{Cl}$ and $\mathrm{CP}-(\mathrm{COOH})_{2}$ were included. Evidence for their

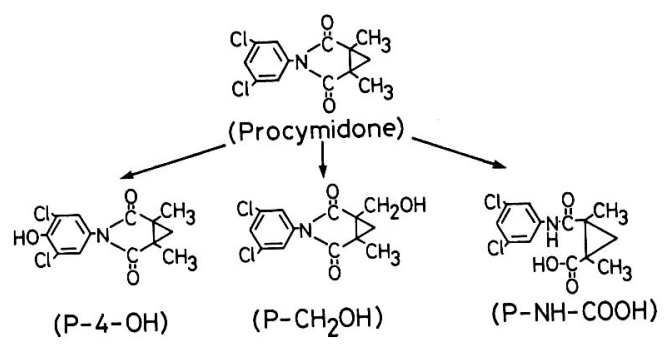

Fig. 3 Metabolic pathways for procymidone in plants.

identity was obtained by TLC cochromatography with the authentic standards.

Thus, although uptake and translocation of procymidone varied to some extents depending upon the routes of application, growth stage of the plants, and soil properties, translocation to the edible portion proceeded only to a limited extent. The identified procymidone metabolites in cucumber and bean plants were analogous to those in mammals ${ }^{4}$ (Fig. 3).

\section{REFERENCES}

1) Y. Hisada, K. Maeda, N. Tottori \& Y. Kawase: J. Pesticide Sci. 1, 145 (1976)

2) Y. Hisada, K. Maeda, Y. Kawase \& J. Miyamoto: J. Pesticide Sci. 1, 201 (1976)

3) Y. Hisada, T. Kato \& Y. Kawase: Neth. J. Plant Pathol. 83, 71 (1977)

4) N. Mikami, H. Satogami \& J. Miyamoto: $J$. Pesticide Sci. 4, 165 (1979)

5) A. Yoshitake, I. Nakatsuka \& H. Tsunematsu: Radioisotopes 26, 31 (1977)

6) A. Fujinami: unpublished observation

7) N. Mikami, N. Takahashi, K. Hayashi \& J. 
Miyamoto: J. Pesticide Sci. 5, 225 (1980)

8) N. Mikami, H. Gomi \& J. Miyamoto: Chemosphere 8, 305 (1979)

9) J. Ohnishi: unpublished observation

10) C. A. Peterson \& L. V. Edgington: Phytopathology 61, 91 (1971)

11) N. Mikami \& J. Miyamoto: Rev. Plant Prot. Res. 14, 85 (1981)

12) R. D. Carringer, J. B. Weber \& T. J. Monaco: J. Agric. Food Chem. 23, 568 (1975)

13) P. A. Wahid \& N. Sethunathan: J. Agric. Food Chem. 26, 101 (1978)

14) A. Felsot \& P. A. Dahm: J. Agric. Food Chem. 27, 557 (1979)

\section{要約}

殺菌㨈プロシミドンのキュウリおよびインゲン マメにおける移行と代謝

三上信可, 吉村 淳, 山田宏彦, 宮本純之 浸透移行性殺菌剂プロシミドン(スミレックス®)のキ
ュウリおよびインゲンマメにおける代謝について検討し た. ${ }^{14} \mathrm{C}$ 標識体を $250 \mu \mathrm{g} /$ 葉 の割合で葉面処理して温室 内で栽培すると，プロシミドンは可食部を含む他の無処 理部にほとえど移行することなく，両植物ともに半減期 が約 20 日の速度で減少した。. ${ }^{14} \mathrm{C}$ 標識体をキュウリ果実 表面に 7.5 10 ppm の割合で処理すると，処理 1 日後 に添加 ${ }^{14} \mathrm{C}$ の約 $24 \%$ が果実内部に浸透したものの，そ の後増加する傾向は認められなかった，本化合物は，可 食部を含む植物体内に打いて，メチル基の水酸化，フェ ニル基 4 位の環水酸化，環状イミドの加水分解を経て徐 徐に代謝された。一方, ${ }^{14} \mathrm{C}$ 標識体を $10 \mathrm{ppm}$ の割合で 処理した小平軽埴土や宝塚壇質砂土にインゲンマメを移 植して 42 日間栽培すると, 地上部には $12.3 \sim 15.3 \mathrm{ppm}$ の ${ }^{14} \mathrm{C}$ が存在したが, 可食部に扔ける ${ }^{14} \mathrm{C}$ 残留量は 0.42 0.66 ppm であった. プロシミドン処理土塨を好 気的畑地条件で 5 力月間前もってインキュべートする と，土塨からインゲンマメに取りこまれる ${ }^{14} \mathrm{C}$ が著しく 低下した。 